\title{
Correction to: NMDA Receptors Regulate Neuregulin 2 Binding to ER-PM Junctions and Ectodomain Release by ADAM10
}

\section{Detlef Vullhorst ${ }^{1} \cdot$ Andres Buonanno $^{1}$ (i)}

Published online: 14 September 2019

(C) Springer Science+Business Media, LLC, part of Springer Nature 2019

\section{Correction to: Mol Neurobiol}

https://doi.org/10.1007/s12035-019-01659-w

The original version of this article unfortunately contained an error in Title as the authors inadvertently deleted during revisions the last two words of our paper's title ("by ADAM10"), which is very important for explaining the article's content and impact.

With this, the authors hereby publish this correction note to correct the Title from "NMDA Receptors Regulate Neuregulin 2 Binding to ER-PM Junctions and Ectodomain Release" to "NMDA Receptors Regulate Neuregulin 2 Binding to ER-PM Junctions and Ectodomain Release by ADAM10" as presented above.

Publisher's Note Springer Nature remains neutral with regard to jurisdictional claims in published maps and institutional affiliations.

The online version of the original article can be found at https://oi.org/ 10.1007/s12035-019-01659-w

Andres Buonanno

buonanno@mail.nih.gov

1 Section on Molecular Neurobiology, Eunice Kennedy Shriver National Institute of Child Health and Human Development, 35 Lincoln Drive, Room 2C-1000, Bethesda, MD 20892, USA 